\title{
BODY MASS INDEX AND CARPAL TUNNEL SYNDROME
}

\author{
JOAOARIS KOUYOUMDJIAN*, MARIA DA PENHA ANANIAS MORITA **, \\ PAULO RICARDO FERNANDO ROCHA ***, RAFAEL CARLOSMIRANDA***, \\ GUSTAVOMACIEL GOUVEIA***
}

\begin{abstract}
Carpal tunnel syndrome (CTS) has been correlated to body mass index (BMI) increase. The present study was done in a Brazilian population to compare BMI values in the following groups: first, CTS vs. controls subjects, and, second CTS groups of increasing median sensory latency (MSL). According to MSL $\geq 3.7 \mathrm{~ms}$ (wristindex finger, $14 \mathrm{~cm}$ ), median/ulnar sensory latency difference $\geq 0.5 \mathrm{~ms}$ (ring finger, $14 \mathrm{~cm}$ ) or median palm-to-wrist $(8 \mathrm{~cm})$ latency $\geq 2.3 \mathrm{~ms}$ (all peak-measured), 141 cases ( 238 hands) had CTS confirmation. All were symptomatic; previous surgery and polyneuropathy were excluded; mean age $50.3 ; 90.8 \%$ female. Controls subjects $(\mathrm{n}=243$; mean age 43.0; 96.7\% female) and CTS cases had BMI calculated $\left(\mathrm{kg} / \mathrm{m}^{2}\right)$. Controls subjects had a mean BMI of $25.43 \pm 4.80$ versus $28.38 \pm 4.69$ of all CTS cases, a statistically significant difference $(\mathrm{p}<0.001)$. The CTS groups of increasing MSL severity do not show additional increase in BMI (28.44 for incipient, 28.27 for mild, 28.75 for moderate and 29.0 for severe). We conclude that CTS cases have a significant correlation with higher BMI when compared to controls subjects; however, higher BMI do not represent a statistically significant increasing risk for more severe MSL.
\end{abstract}

KEY WORDS: carpal tunnel syndrome, median nerve, compressive neuropathy, body mass index, nerve conduction studies.

\section{Índice de massa corporal e síndrome do túnel do carpo}

RESUMO - Síndrome do túnel do carpo (STC) pode ser estar relacionada ao aumento de índice de massa corporal (IMC). O presente estudo foi realizado em uma população brasileira para comparar valores de IMC entre casos com STC e controles assintomáticos; os casos com STC foram ainda divididos em subgrupos de gravidade progressiva de acordo com a latência distal sensitiva do nervo mediano (LDS-M). Os casos de STC (141, 238 mãos) foram confirmados com LDS-M $\geq 3,7 \mathrm{~ms}$ (punho-II dedo, $14 \mathrm{~cm}$ ), diferença de latência mediano-ulnar $\geq 0,5$ $\mathrm{ms}$ (punho-IV dedo, $14 \mathrm{~cm}$ ) ou latência palma-punho do nervo mediano $\geq 2,3 \mathrm{~ms}(8 \mathrm{~cm})$, todos medidos no pico do potencial. Todos os casos eram sintomáticos; foram excluídos casos com polineuropatia e cirurgia prévia; a média de idade foi 50,3 anos e 90,8\% dos casos eram do gênero feminino. Os controles assintomáticos (243) apresentavam média de idade de 43 anos sendo 96,7\% do gênero feminino. O IMC foi calculado de acordo com a fórmula $\mathrm{Kg} / \mathrm{m}^{2}$. O grupo controle apresentou IMC de 25,43 $\pm 4,8$ contra 28,38 $\pm 4,69$ do grupo com STC ( $\left.\mathrm{p}<0,001\right)$. Os subgrupos de STC com aumento progressivo de LSD-M não mostraram aumento adicional de IMC. Concluimos que o STC apresenta correlação significante com aumento de IMC quando comparado ao grupo controle; contudo, aumento de IMC não representou risco adicional significante de STC mais grave.

PALAVRAS-CHAVE: síndrome do túnel do carpo, nervo mediano, neuropatia compressiva, índice de massa corporal, condução nervosa.

Carpal tunnel syndrome (CTS), a common cause of numbness, paraesthesia and pain in hands due to compression of the median nerve under the transverse carpal ligament, has been correlated to

Department of Neurological Sciences, Electroneuromyography Lab, Medical School, Sao Jose Rio Preto, SP, Brazil: *MD, MSc, Assistant-Professor; **MD, MSc; ***Medical graduation student. Presented on 46 ${ }^{\text {th }}$ American Association of Electrodiagnostic Medicine Scientific Meeting, Vancouver, Canada, October 6-9, 1999. Aceite: 31 -janeiro-2000.

Dr. Joao Aris Kouyoumdjian - Av. Bady Bassitt 3896 - 15025-000 São José Rio Preto SP - Brazil. E-mail:jaris@zaz.com.br 
increased weight and body mass index (BMI). BMI represent an important risk for developing this compressive neuropathy togetherwith some medical conditions such as diabetes mellitus, thyroid diseases, connective tissue disorders, amyloidosis and acromegalia, and also age, gender, wrist dimension, weight and stature. Vessey et al. ${ }^{1}$ described a double risk of developing CTS among obese women when compared to slender ones. Nathan et al. ${ }^{2}$ also demonstrated in an industrial population, that higher BMI was correlated to a relative increase risk for developing median mononeuropathy. Werner et al. ${ }^{3}$ found that median mononeuropathy at the wrist was 2.5 times more likely to occur in those individuals classified as obese (BMI > 29) when compared to slender ones (BMI < 20).

The present study was done in a Brazilian population to compare BMI values in the following groups: first, CTS vs. control subjects; and second, CTS subjects grouped according to median sensory peak-latency severity. The aim of this study was to investigate the influence of higher BMI in the severity of CTS (median sensory conduction) and also to compare our results of BMI values in CTS cases and control subjects to literature.

\section{METHOD}

\section{Subjects}

From September 1998 to January 1999, 141 consecutive subjects referred for electrodiagnostic consultation for CTS confirmation were included. All subjects were symptomatic and at least nocturnal and/or awakening numbness and/or paraesthesia in one or both hands were found. Cases with previous CTS surgery and subjects with clinical or electrophysiological evidence of polyneuropathy were excluded from the study. Subjects with diabetes mellitus were not excluded unless their electrophysiological examination demonstrated a polyneuropathy. From the total 141 subjects included in the study, 97 had bilateral CTS confirmation (68.7\%), 29 have right CTS (20.6\%) and 15 had left CTS (10.6\%); therefore, 238 hands were included in the study. The mean age was 50.3 years, ranging from 26 to 79 . There were 128 women (90.8\%) and 13 men (9.2\%) in the study. Two hundred forty three asymptomatic controls had their BMI calculated. The mean age was 43.0 years, ranging from 17 to 86 . There were 235 women (96.7\%) and 8 men (3.3\%) in the control group. The protocol was approved by the local ethics committee of our institution, and all subjects gave their informed consent to have their measures taken in the study.

Body mass index

The BMI, a good general indicator of body fat content, was calculated as weight (kilograms) divided by height (meters) squared $\left(\mathrm{kg} / \mathrm{m}^{2}\right)$.

Nerve conduction studies

Standard nerve conduction studies were performed on CTS subjects by the first 2 authors (JAK/MPAM) using DANTEC, Cantata (Denmark), and, LBM-4E (USA) for the recordings, and, at least one abnormal test was found among three described at the following. Sensory nerve conduction studies were performed antidromically.

Wrist to index finger (WIF): supramaximal intensity stimuli starting at $0.05 \mathrm{~ms}$ duration and occasionally increased to 0.10 when necessary was applied at the wrist, $14 \mathrm{~cm}$ proximal to the active recording at the index finger (ring electrodes). The sweep speed was set at 1-2 ms/div with the gain at 10-20 uV/div. The latency was measured to the peak of the evoked sensory nerve action potential and values equal or above $3.70 \mathrm{~ms}$ were considered abnormal.

Median to ulnar peak difference (MUD): supramaximal intensity stimuli starting at $0.05 \mathrm{~ms}$ duration and occasionally increased to 0.10 when necessary was applied at the wrist, $14 \mathrm{~cm}$ proximal to the active recording at the ring finger (ring electrodes). The sweep speed was set at 1-2 ms/div with the gain at 10-20 uV/div. The peak latency difference between median and ulnar evoked sensory nerve action potentials was calculated and values equal or above $0.50 \mathrm{~ms}$ were considered abnormal. Mixed nerve conduction study was performed orthodromically.

Median palmar latency (PW): supramaximal intensity stimuli starting at $0.05 \mathrm{~ms}$ duration and occasionally increased to 0.10 when necessary was applied at the midpalm, $8 \mathrm{~cm}$ distal to the active recording at the wrist (bar electrode). The sweep speed was set at 1-2 ms/div with the gain at 10-20 uV/div. The latency was measured to the peak of the evoked mixed nerve action potential and values equal or above $2.30 \mathrm{~ms}$ were considered abnormal. Palmar temperature was maintained above $32^{\circ} \mathrm{C}$ using digital thermometer (BRAILE BIOMEDICA, Brazil). 
Table 1. BMI in control subjects and in CTS cases with increasing MSL severity.

\begin{tabular}{lccccc}
\hline & & Cases & Hands & BMI mean(SD) & p \\
\hline Controls subjects & 1 & 243 & - & $25.43(4.80)$ & - \\
CTS & 2 & 141 & - & $28.38(4.69)$ & $1 / 2=0.000$ \\
MSL 2.9 to 3.6 ms & 3 & - & 69 & $28.44(5.34)$ & - \\
MSL 3.7 to 4.4 ms & 4 & - & 81 & $28.27(3.77)$ & $3 / 4=0.820$ \\
MSL > 4.4 ms & 5 & - & 69 & $28.75(5.01)$ & $3 / 5=0.726$ \\
MSL unrecordable & 6 & - & 19 & $29.00(3.80)$ & $3 / 6=0.670$ \\
\hline
\end{tabular}

BMI, body mass index; CTS, carpal tunnel syndrome; SD, standard deviation; MSL, median sensory peak-latency.

Groups

WIF was used to define CTS severity and four groups were constituted according to peak-latency as described above. Incipient: 2.9 to $3.6 \mathrm{~ms}$ (normal WIF values but abnormal MUD and/or PW); Mild: 3.7 to 4.4 ms; Moderate: > $4.4 \mathrm{~ms}$; and Severe: unrecordable sensory nerve action potential.

Statistics

Student $t$ test was used to compare the difference between means and standard deviation for the variables in controls subjects and CTS groups.

\section{RESULTS}

The results are showed on Table 1. Controls subjects have a mean BMI of $25.43 \pm 4.80$ versus $28.38 \pm 4.69$ of all CTS cases, a statistically significant difference $(\mathrm{p}<0.001)$. The CTS groups of increasing median sensory peak-latency severity do not show additional increase in BMI (28.44 for incipient, 28.27 for mild, 28.75 for moderate and 29.0 for severe).

\section{DISCUSSION}

Dieck and Kelsey ${ }^{4}$ studying characteristics of 40 CTS cases and 1,043 controls subjects found that a recent weight gain was identified as possible risk factor, supporting the theory that fluid retention in the soft tissues of the carpal tunnel is etiologically involved. They found a mean BMI of 27.0 in CTS cases and 25.0 in controls subjects. Vessey et al. ${ }^{1}$ studying a sample of 156 women with supposed severe CTS from the Oxford-family planning clinics (17,032 women) found statistically significant relationship between first hospital referral for CTS and Quetelet's obesity index (same as BMI). De Krom et al. ${ }^{5}$ studying the risk factors for CTS in 156 patients and 473 controls subjects found that slimming courses has a twofold risk for CTS and it could be related to the risk of weight since heavier persons are more likely to take slimming courses. Nathan et al. ${ }^{2}$ in a longitudinal study of the etiology of CTS in industrial workers found a highly significant increase in average BMI in female workers presenting with median slowing after 5 years follow-up. There is a suggestion that individuals characteristics such as BMI, age, wrist dimensions and hand dominance are more important in determining the health of the median nerve than are job-related factors such as occupational hand use, duration of employment, or industry. BMI is an important risk factor for slowing of median nerve sensory conduction in industrial workers and a useful predicting for those who subsequently would develop slowing (5 years study). Werner et al. ${ }^{3}$ studying 949 subjects ( 261 diagnosed with median mononeuropathy at the wrist) found that only $16 \%$ of slender individuals (BMI < 20) were diagnosed with CTS compared to $39 \%$ of the obese subjects (BMI > 29). Obese individuals are 2.5 times as likely to have the diagnosis of CTS compared to a group of slender individuals. The mean BMI for those individuals with CTS was 28.9 and 26.2 in the remainder of the population. They also found that BMI is correlated with median but not ulnar sensory distal latencies suggesting that the 
condition of obesity affect the nerves differently. Radecki ${ }^{6}$ found that prolongation of median latencies were associated with increased BMI regardless symptoms were considered related to work or not. The mean BMI was 30.42 in men and 31.19 in women with median slowing (CTS) and 26.99 in men and 27.07 in women without median slowing. Albers et al. ${ }^{7}$ studying median mononeuropathy in diabetics found that type II patients with median mononeuropathy had higher BMI than the remaining type II patients (32.5 vs. 29.1). There was a tendency for the frequency of median mononeuropathy to increase with increasing BMI, although the relationship reached statistical significance only for type II patients. Nordstrom et al. ${ }^{8}$ studying risk factors for CTS in a general population, found that for each unit increase in BMI, risk of CTS increased 8\%, concluding a strong correlation between BMI and CTS. Stallings et al. ${ }^{9}$ in 1997 studying 300 CTS and 300 controls subjects found $46 \%$ of CTS group having a BMI of 30 or higher and just $18 \%$ on the control group. The average BMI of the study group (CTS) was 30.15 and 25.96 for the control group. The findings of this study also support the hypothesis that obesity is a risk factor for CTS. Buschbacher in $1998^{10}$ studying 253 normal subjects found that BMI increase correlates significantly with reduced sensory and mixed nerve amplitude; the mean values were approximately $20-40 \%$ lower in the obese than in the thin subjects. No correlation was noted between BMI and nerve conduction velocity, H-reflex latency and most of the other motor, sensory and mixed measures. Lam and Thurston ${ }^{11}$ studying 96 patients from an original group of 512 CTS subjects that required surgical decompression found that the number of overweighed female patients $(73.68 \%)$ was more than twice compared to females in the general population of New Zealand (36.49\%); similar numbers occurred in male population.

The causal relationship between CTS and increase BMI could be due to increase fatty tissue within the carpal canal or to increased hydrostatic pressure throughout the carpal canal in obese individuals ${ }^{3}$. Radecki ${ }^{12}$ commented that individuals of increased BMI have presumably increased translocated blood volume from the legs after assumption of the recumbent position. This additional volume goes somewhere other than the thorax; an increase fluid volume in the arms during recumbency would swell the veins of the flexor synovials and raise tissue pressure in the carpal tunnel. Such synovial engorgement explains both the edema without inflammation and the elevated mean tissue pressures found in carpal tunnel above critical pressure in patients undergoing carpal tunnel surgery.

Our results correlating BMI and CTS and normal controls are similar of those works described in the literature (Table 2). We found mean BMI of 28.38 in $141 \mathrm{CTS}$ cases and 25.43 in 243 normal Brazilian controls. The most remarkable result of the present work is that we could not find correlation between BMI and median sensory latency severity in CTS population. Higher BMI increases the risk of developing CTS but could not increase its severity.

Table 2. Comparison of BMI values in CTS and normal subjects (controls) in 5 articles.

\begin{tabular}{lcccc}
\hline & BMI/CTS & $\mathrm{n}$ & BMI/Controls & $\mathrm{n}$ \\
\hline Dieck and Kelsey, 19854 & 27.0 & 40 & 25.0 & 1043 \\
Werner and Albers, 1994 & $28.90 \pm 6.80$ & 261 & $26.20 \pm 6.00$ & 688 \\
Radecki, 1995 & $30.42 \pm 5.20 \mathrm{M}$ & 341 & $26.99 \pm 4.59 \mathrm{M}$ & 180 \\
& $31.19 \pm 7.49 \mathrm{~F}$ & 545 & $27.07 \pm 5.99 \mathrm{~F}$ & 406 \\
Stallings et al., 19979 & $30.15 \pm 5.90$ & 300 & $25.96 \pm 5.04$ & 300 \\
Kouyoumdjian et al., 1999* & $28.38 \pm 4.69$ & 141 & $25.43 \pm 4.80$ & 343 \\
\hline
\end{tabular}

BMI, body mass index; CTS, carpal tunnel syndrome; $n$, number; $M$, male; F, female.

*Present series. 
We conclude that CTS cases have a significant correlation with higher BMI when compared to controls subjects; however, higher BMI does not represent a statistically significant increasing risk for more severe CTS cases according to MSL.

\section{REFERENCES}

1. Vessey MP, Villard-Mackintosh L, Yeates D. Epidemiology of carpal tunnel syndrome in women of childbearing age: findings in a large cohort study. Int J Epidemiol 1990;19:655-659.

2. Nathan PA, Keniston RC, Myers LD, Meadows KD. Obesity as a risk factor for slowing of sensory conduction of the median nerve in industry: a cross-sectional and longitudinal study involving 429 workers. J Occup Med 1992;34:379-383.

3. Werner RA, Albers JW, Franzblau A, Armstrong TJ. The relationship between body mass index and the diagnosis of carpal tunnel syndrome. Muscle Nerve 1994;17:632-636.

4. Dieck GS, Kelsey JL. An epidemiologic study of the carpal tunnel syndrome in an adult female population. Preventine Medicine 1985;14:63-69.

5. De Krom MC, Kester AD, Knipschild PG, Spaans F. Risk factors for carpal tunnel syndrome. Am J Epidemiol 1990;132:1102-1110.

6. Radecki P. Variability in the median and ulnar nerve latencies: implications for diagnosing entrapment. J Occup Environ Med 1995;37:1293-1299.

7. Albers JW, Brown MB, Sima AA, Greene DA. Frequency of median mononeuropathy in patients with mild diabetic neuropathy in the early diabetes intervention trial (EDIT). Tolrestat Study Group for Edit. Muscle Nerve 1996;19:140-146.

8. Nordstrom DL, Vierkant RA, DeStefano F, Layde PM. Risk factors for carpal tunnel syndrome in general population Occup Environ Med 1997;54:734-740.

9. Stallings SP, Kasdan ML, Soergel TM, Corwin HM. A case-control study of obesity as a risk factor for carpal tunnel syndrome in a population of 600 patients presenting for independent medical examination. J Hand Surg 1997;22:211-215.

10. Buschbacher RM. Body mass index effect on common nerve conduction study measurements. Muscle Nerve 1998;21:1398-1404.

11. Lam N, Thurston A. Association of obesity, gender, age and occupation with carpal tunnel syndrome. Aust N Z Surg 1998;68:190-193.

12. Radecki P. Personal factors and blood volume movement in causation of median neuropathy at the carpal tunnel: a commentary. Am J Phys Rehabil 1996;75:235-238. 